\title{
The ecological and economic sustainability of environmental education
}

\author{
Gufran Darma Dirawan \\ Civil Engineering \\ Universitas Negeri Makassar \\ Makassar, Indonesia \\ gufrandarma@yahoo.com
}

\begin{abstract}
The City of Makassar, South Sulawesi, has to experience environmental problems as a result of urbanization and physical development of the city. The ecological functions of the city are decreasing as a result of increasingly extensive urban infrastructure, that is why Environmental education system can be an alternative to improve the balance of the urban environment and social-economic of urban communities. This study aims at analyzing the ecological and economic sustainability level as well as to determine the factors sensitive determinant of sustainability of environmental education programs in the city of Makassar. This research uses MDS method called Rap-Edu-Enviro to analyze the index and sustainability status of environmental education programs. Data collected from an interview with relevant experts and stakeholders. The results of the multidimensional analysis show that sustainability index value of environmental education programs is $\mathbf{4 8 . 5 2 \%}$ which is less sustainable status, but partially the index value of ecologic and economic dimensions respectively 42.66 \% with a status less sustainable and $50.69 \%$ with a reasonably sustainable status. The leverage analysis of attributes the ecological dimension shows the sensitive attributes were the condition of land use sanitation, organic waste treatment, and the dominant plant species used in environmental education programs. Attributes of the economic dimension consist of seven sensitive attributes. Analysis of Rap-Edu-Environ showed an appropriate and valid $(\mathrm{R} 2>0.90$ and $S<0.25)$ to evaluate the level of sustainability of environmental education programs in the city of Makassar.
\end{abstract}

Keywords - environmental education programs; sustainable index; MDS (Multi-Dimension Scaling) method

\section{INTRODUCTION}

A sustainable city becomes an essential issue of all city in Indonesia because the development of the city become more expansive to utilize space of the natural spaces that have ecological functions. This phenomenon occurs due to increase the rate of population growth and urbanization as well as the physical development of the city. In Indonesia's Economic Vision 2025, it has been estimated that $65 \%$ of Indonesia's population will live in the city. The phenomenon of the population growth and urbanization will have an impact on the sustainability of the environmental aspects and socio-economy of a city.

The increase in the urban population without the support and offset the provision of food/ nutrition, employment, housing facilities, as well as facilities and infrastructure to support other life would cause problems of social-economic urban, such as urban poverty and food security [1]. Similarly, the use of urban spaces that are not well planned and ignores the ecological functions has been causing the increasing environmental problems [2].

One of the critical strategies in overcoming problems of the urban environment is the development of environmental education programs. Environmental education programs are part of education programs that aim to improve community knowledge, attitudes and behavior to protect and preserve their environment. These programs can improve impact on the social-economic aspect of community and environmental sustainability of the city so that it becomes an integral part of sustainable development [3][4]. Moreover, environmental education programs have multiple functions. The most function is improving the capacity of knowledge of the community, sustainable solution for education [5][6]. The second function is improving environmental functions that can play a leading role in the decarbonization by decreasing $\mathrm{CO} 2$ emissions, reducing the environmental impact of the building, reducing transport emissions, improving the recycling of resources, reduce waste of the city, the climate balance of the city, and taking pressure off agricultural land. The next function is improving the panorama of the city that is forming the landscape of the city as well as improving the socioeducational for the public [7][6]. The last function is improving the local economy and job vacancy [8].

In Indonesia, environmental education programs are a form of the revitalization of the education sector to support the development of the sustainable city. Environmental education programs associated with the promotion of community behavior, improvement the city landscape, an environmental education facility for residents of the city, hobbies/pleasure, as well as a livelihood for the urban poor. Also, the development of environmental education programs can support the implementation of government programs, i.e., green and clean city. The concept of urban development for the city as a provider of food for its citizens [9].

Makassar as a metropolitan city and regional development center in the Eastern part of Indonesia with some populations of $1,408,072$ people [10] there are also the problems of population and urbanization as well as environmental imbalances. This indicator can be seen from the growing 
urban needy families, the availability insecurity of food and nutrition, reduced urban green open space both quantitatively and qualitatively. Availability of green open space of exiting the city of Makassar only $9.2 \%$ and its equivalent to an area of 379.7 ha and has decreased each year [10]. Makassar city government has tried to deal with urban environmental and social-economic problems and has been conceived and implemented with varying success achieved, for example, a green city program. Implementing the concept of the green city is carried out in the form of environmental education programs activities in open spaces, roofs of buildings and public housing yard, and the yard office.

The effort that has been pursued by the government in the development of environmental education programs is a complex system involving various components and elements of integrated. Sustainability is strongly influenced by the behavior of the community components of the support system. The object of research studies focused on the analysis of the level of sustainability of ecological and economic aspects of the development of environmental education. This study also can be used to develop government especially in education sector strategies and policies for the development of education system in the city of Makassar

\section{RESEARCH METHOD}

The research was conducted in the city of Makassar, South Sulawesi, by using survey method. The sample consists of five sub-districts of 14 districts. This research conducted in March through August 2016. The data used to describe the sustainability index value of ecological and economic dimensions, which were the result of interviews with stakeholders and relevant expert. Stakeholders were selected purposively consist of the Government officers of the City (Department of Sanitation and Landscaping, education institutions, the Regional Environmental Agency), community leaders, political figures, the community of users, practitioners of environmental education programs, education experts and observers, NGOs, professional environmental educations.

The analytical method uses the technique of MultiDimensional Scaling (MDS) called Rap-Edu-Environ (Rapid Assessment for Environmental education programs Makassar). MDS method implemented in a computer program by using Microsoft Office Excel Add-Ins Raffish. This method is a modification of the approach RAPFISH (Rapid Appraisal for Fisheries) developed by Fisheries Centre, University of British Columbia, Canada [11], [12]. The output of this analysis is the scale index and sustainability status of each dimension and multidimensional.

The attributes used in 23 attributes, respectively: 13 attributes of the ecological dimension and ten attributes of the economic dimension in assessing the sustainability of environmental education programs in the city of Makassar. The attributes for each dimension has been assessed by scoring. The range of scores between 0 to 3 was interpreted from bad to good and a score definitive analyzed is the mode value to determine the points positions relative to the sustainability of the good and bad points [11], [13].
The range of sustainability index and sustainability status grouped four categories: 0 to $25 \%$ terrible categories (unsustainable), from 25.01 to $50 \%$ (less sustainable), from 50.01 to $75 \%$ (reasonably sustainable) and 75.01 to $100 \%$ good categories (highly sustainable). The accuracy of the measurement model (good fit) each dimension and attribute in MDS is reflected through stress value (S) is less than 0.25 ( $\mathrm{S}$ $<0.25$ ) and the coefficient of determination (R2) approaches a value of 1 or $100 \%$. The analyses show that selected attributes can account for nearly $100 \%$ current conditions [12], [14]. Furthermore, the Leverage analysis is used to determine the sensitivity attribute of sustainability through changes of Root Mean Square (RMS) in the ordination on the X-axis. The more considerable change of the RMS values of an attribute, the more sensitive or dominant role these attributes to the improvement of the sustainability status. Analysis of the index Monte Carlo used to predict an error rate of analysis in the $95 \%$ confidence interval.

\section{RESEARCH RESULT}

\section{A. Multi-Dimensional Sustainability}

The analysis of MDS Rap-Edu-Enviro shows that the index value of multidimensional sustainability of environmental education programs in the city of Makassar is $48.52 \%$, where the index value in the range of 25.01 to $50 \%$ showing less sustainable status. The dimensions and attributes used in this analysis represent a model with the goodness of fit. Analysis of Stress value $0.131(<0.25)$ and the value of determination (R2) was 0.957 ( $>90 \%$ or close to $100 \%$ ) is quite high. According to Kavanagh (2001) and Alder et al. (2003) means that the model goodness of fit. Also, the difference in the value of the index Monte Carlo $(95 \%$ confidence level) and the index value of MDS Rap-EduEnviron are relatively small or not significant (Table 1). The state explained that the simulation using MDS Rap-EduEnviron have a high level of confidence [12].

TABLE I. VAlue OF INDEX MDS, MONTE CARlo, StRess VAlue ( S ) AND THE COEFFICIENT OF DETERMINATION ( R2 )

\begin{tabular}{|c|c|c|c|c|c|c|}
\hline \multirow{2}{*}{$\begin{array}{l}\text { Dimensions of } \\
\text { Sustainability }\end{array}$} & \multicolumn{3}{|c|}{ Sustainability indexes (\%) } & \multicolumn{2}{|c|}{ Value of } & \multirow[b]{2}{*}{$\begin{array}{c}\text { Sustainability } \\
\text { Status }\end{array}$} \\
\hline & $M D S$ & $\begin{array}{c}\text { Monte } \\
\text { Carlo }\end{array}$ & Difference & $\begin{array}{c}\text { Stress } \\
(S)\end{array}$ & $R 2$ & \\
\hline Ecology & 42.66 & 40.31 & 2.35 & 0.137 & 0.953 & $\begin{array}{l}\text { Less } \\
\text { sustainable }\end{array}$ \\
\hline Economic & 50.69 & 50.47 & 0.21 & 0.149 & 0.947 & $\begin{array}{l}\text { Enough } \\
\text { sustainable }\end{array}$ \\
\hline Multidimension & 48.52 & 48.62 & 0.10 & 0.131 & 0.957 & $\begin{array}{l}\text { Less } \\
\text { sustainable }\end{array}$ \\
\hline
\end{tabular}

\section{B. Ecological Dimensions Sustainability}

Analysis of the sustainability of ecological dimension carried out some attributes. The attributes are the community knowledge of the rate of land conversion, backyard area, and the rate of land use. The next is the community knowledge of the fruit trees dominant type that can be cultivated. The attributes are followed by the community knowledge of vegetable crops dominant, the aesthetic value of the environment settings, the value of the ecological function of 
environmental education programs, organic waste treatment. Other attributes are the community knowledge of the use of fertilizers and pesticides and community knowledge of change climate. The other attributes are the community knowledge of the potential for flood events as well as the community knowledge of productive green open space.

Analysis of MDS Rap-Edu-Environ shows that the sustainability index value of the ecological dimension is 42.66 $\%$, and the index value on the range of $25.01-50 \%$ showing less sustainable. Furthermore, the leverage analysis of ecological dimension attribute shows the four attributes of sensitive or dominant influence on the value of sustainability index, i.e. irrigation conditions, the level of use of fertilizers and pesticides, organic waste treatment, and the dominant plant species cultivated (Figure 1).
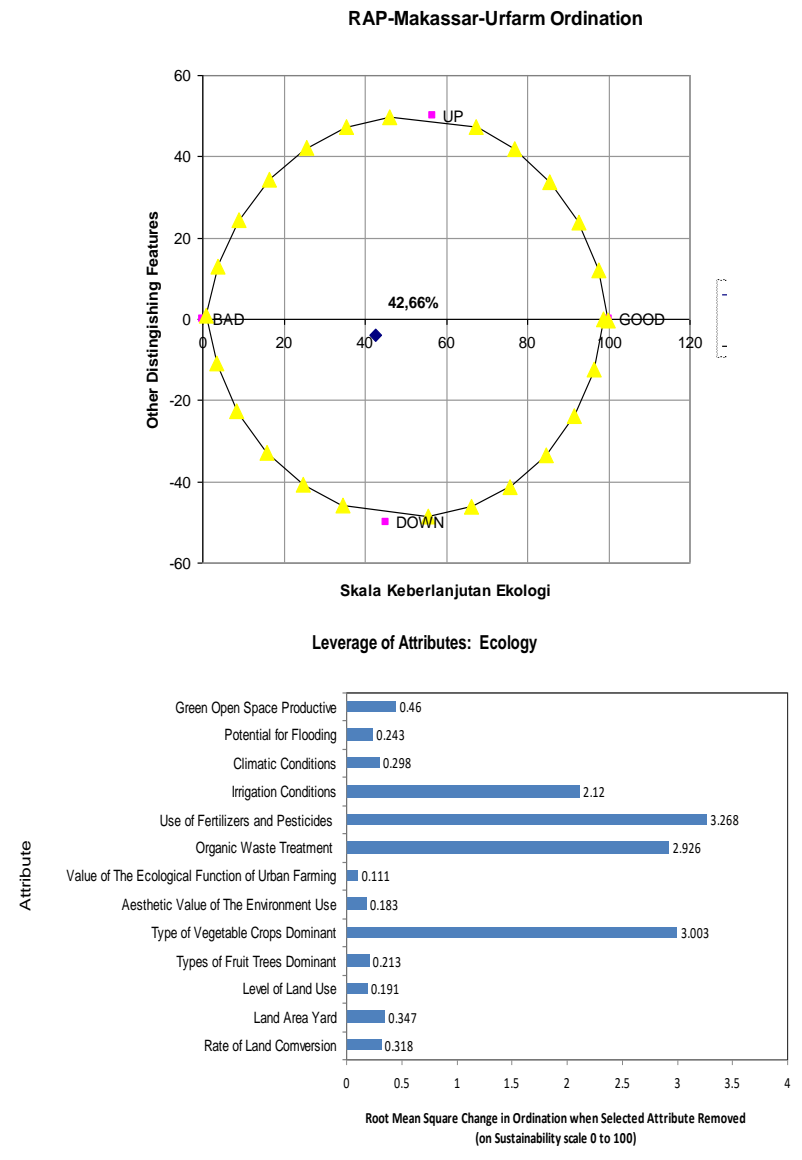

Fig. 1. Analysis of Index and Leverage/Sensitivity of Dimension Ecology Sustainability

\section{Economic Dimension Sustainability}

Analysis of the sustainability of the economic dimension carried out on some attributes. The first is the need for environmental education programs inputs. The second is the price of environmental education programs inputs. The third id provision of incentives environmental education programs. The fourth is the community knowledge of the productivity of the plant. The fifth is the contribution of environmental education programs income to the family economy. The sixth is the availability of capital for environmental education programs. The seventh is the economic feasibility of environmental education programs, the type of plant. The eight is the contribution rate of environmental education programs for food/nutrient of the household. The ninth is a source of employment/economic improvement of poor communities.
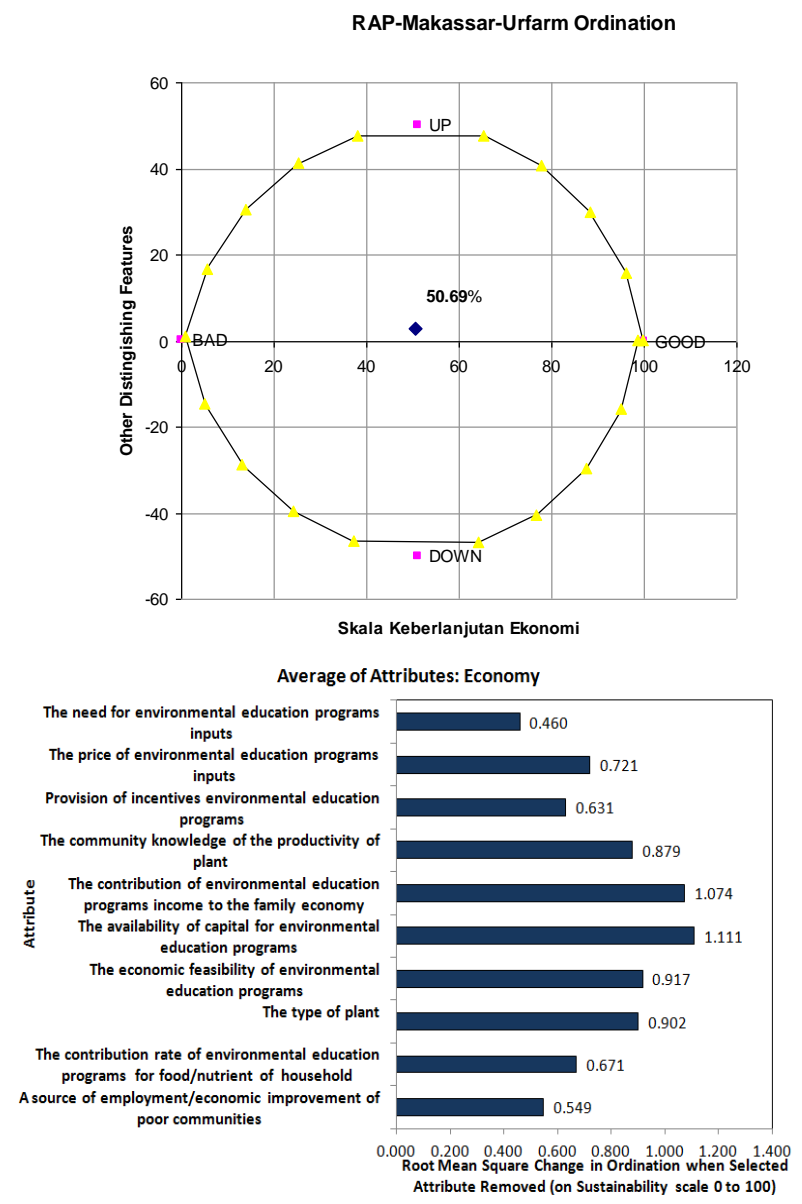

Fig. 2. Analysis of Index and Leverage/Sensitivity of Dimension Ecology Sustainability

The analysis of MDS Rap-Edu-Enviro shows that the index value of sustainability of economic dimension is 50.69 $\%$, and the index value on the range of $50.01-75 \%$ showing Sustainable enough. Furthermore, the leverage analysis of economic dimension attribute shows some attributes of sensitive or dominant influence on the value of sustainability index. The frist attribute is the contribution of environmental education programs income to the family economy. The second attribute is the availability of capital for environmental education programs. The third is the productivity of crops cultivated. The fourth is provision of incentives environmental education programs. The fitth attribute is the economic feasibility of environmental education programs. The sixth is the contribution rate of environmental education programs for food/nutrient of household the contribution of environmental education programs to the needs of households. The seventh is the price of environmental education programs inputs (Figure 2). 


\section{Discussion}

Environmental education programs can provide ecological and economic advantages for people in urban areas [15]. Environmental education programs can be economically contributed to improving the efficiency of the livestock food production and food supplies to the town (Aubry et al. 2010). The ecological functions of environmental education programs can improve community knowledge and attitudes to manage their pollution and contribute to cleaning up the city by using the waste management, as an element of urban landscaped [16], [17]. The existence of environmental education programs needs to be maintained and improved as it has multifunctional that can support the implementation of the concept of the green city or Eco-City [1].

The results of this study indicate that the development of environmental education programs as a multidimensional impact less sustainable at the city of Makassar. Environmental education programs still require improvements to components sensitive attributes that affect sustainability, but governments and education stakeholders can do improvement interventions. According to Moore (2005) sustainability of environmental education programs is a multidimensional approach can use internal and external. The internally approach to conduct a detailed study of the types of environmental education programs technology that is appropriate for a region. Externally approach is needed to improve understanding of the community by doing and dealing with the government to promote environmental education programs and the public in planning the location of the development of environmental education programs.

Partially analysis shows that ecological dimension is less sustainable, the index value of $42.66 \%$ (Table 1 and Figure 1). Ecological dimension needs to get improvement interventions on sensitive attributes in the improvement of sustainability so that the role of the ecological functions of environmental education programs can provide beneficial and sustainable impact in the future. If there is not improvement efforts, then the existence of environmental education programs increasingly unsustainable for the environment and ecological balance functions in the city of Makassar.

Environmental education programs activities have not been applying the principles of environmentally friendly, for example, management and use of resources of urban organic waste have not been fully implemented. Agricultural technologies developed by the people of the city there is a tendency to be high external input so that it will be a threat to environmental sustainability. According [8] in the context of the environment and ecology, the most critical issue is how to identify and technically develop the solution of environmental sustainability. The development and adoption of environmentally friendly agricultural technologies become priorities for the government and stakeholders of urban agriculture [17].

However, partially of sustainability index value of the economic dimension is $50.69 \%$, it is mean that sustainability status is adequate sustainable (Table 1 and Figure 2). These results indicate that environmental education programs can create an impact to improve economic benefits for the city of
Makassar. The same result, environmental education programs research has been done in other developing countries and has been recommended extensively about the benefits provided environmental education programs. The local city government has made plans and policies to support the development of environmental education programs [1]. The development of environmental education programs with proper management will be able to improve economic growth, improve food quality, created healthy communities [4]. The economic benefits of environmental education programs is improving the lives of urban poor households through improved food consumption and reduce the cost of food for the urban poor [19]. Antoher benefit is diversificating sources of income of the people the city [20] empowering women in urban areas [21], [22]. The economic potential is achievable because environmental education programs can be developed, both outdoor and indoor according to environmental conditions, available technologies and crop types appropriate urban areas. The economic role of environmental education programs in the future will be more strategic because it can provide benefits to urban communities. According to [8], it requires the support of the city government policies in providing facilities and incentives supporting the implementation of environmental education programs.

Leverage Analysis of the 23 attributes of sustainability shows that there are 11 attributes sensitive, i.e. four attributes of ecological dimension and seven attributes of the economic dimension. The sensitive attributes become the dominant factor in influencing the sustainability of the development of urban agriculture in Makassar. The sensitive attributes requires attention and better handling if there is no improvement, then the existence of urban agriculture will not be sustainable in the future [13].

Analysis MDS Rap-Edu-Enviro has a high level of accuracy (goodness of fit) as the estimated value of sustainability index of environmental education programs in the city of Makassar. This indication is based on the coefficient of determination (R2) is quite high at over $90 \%$ (from 94.70 to $95.70 \%$ ), and the value of Stress (S) is lower than 0.25 (between 0.131 to 0.149 ). Furthermore, the difference between the value of the index Monte Carlo with an index value of MDS Rap-Edu-Enviro is less than $5 \%$, i.e. $3.37 \%$. This indicates that the simulation method MDS RapEdu-Enviro have a high confidence level and can be used to evaluate the sustainability index of environmental education programs developed in the city of Makassar.

\section{CONCLUSIONS}

The development of environmental education programs in the city of Makassar has less sustainable status with the index $48.52 \%$ multidimensional. Partially of economic dimensions have enough sustainable status with $50.69 \%$ index, while the ecological dimension has less sustainable status with the index $42.66 \%$. Moreover, Of the 23 attributes of sustainability dimensions analyzed there were 11 attributes need to be taken care immediately because of the sensitive effects the increase of index and sustainability status of environmental education programs in the city of Makassar. The analysis of MDS RapEdu-Enviro appropriate and valid with a high confidence level 
to assess the sustainability index of the ecological and economic dimension of environmental education programs in the city of Makassar.

\section{ACKNOWLEDGMENT}

Thanks to The Director General of Higher Education Ministry of Research, Technology and Higher Education, the Republic of Indonesia on funding of research for scheme "PNBP" Grant Fiscal Year 2016.

\section{REFERENCES}

[1] S. T. Lovell, "Multifunctional urban agriculture for sustainable land use planning in the United States," Sustainability, vol. 2, no. 8, pp. 2499-2522, 2010.

[2] M. Alberti, "Maintaining ecological integrity and sustaining ecosystem function in urban areas," Curr. Opin. Environ. Sustain., vol. 2, no. 3, pp. 178-184, 2010.

[3] H. De Zeeuw, "Cities, climate change and urban agriculture," Urban Agric. Mag., vol. 25, pp. 39-42, 2011.

[4] H. Grover and S. Wahee, "SUSTAINABILITY THROUGH URBAN FARMING: A CASE STUDY ON PRIYANKA AMAR SHAH-WOMAN ECOPRENEUR," Int. J. Retail. Rural Bus. Perspect., vol. 2, no. 3, p. 600, 2013.

[5] A. N. Priyanka and Y. P. Choudary, "SUSTAINABLE DEVELOPMENT MANAGEMENT-EXPERIENCES IN EDUCATIONAL ENVIRONMENT," Online J. ISSN, vol. 2347, p. 9671.

[6] C. Aubry, J. Ramamonjisoa, M.-H. Dabat, J. Rakotoarisoa, J. Rakotondraibe, and L. Rabeharisoa, "Urban agriculture and land use in cities: An approach with the multi-functionality and sustainability concepts in the case of Antananarivo (Madagascar)," Land use policy, vol. 29, no. 2, pp. 429-439, 2012.

[7] H. De Bon, L. Parrot, and P. Moustier, "Sustainable urban agriculture in developing countries: a review," in Sustainable Agriculture, Springer, 2009, pp. 619-633.

[8] K. Specht, R. Siebert, I. Hartmann, U. B. Freisinger, M. Sawicka, A. Werner, S. Thomaier, D. Henckel, H. Walk, and A. Dierich, "Urban agriculture of the future: an overview of sustainability aspects of food production in and on buildings," Agric. Human Values, vol. 31, no. 1, pp. 33-51, 2014.

[9] W. Adiyoga, "Prospek pengembangan pertanian urban(perkotaan). Disampaikan pada Dişeminasi Prospek
Pengembangan Sayuran di Perkotaan.” Balai Penelitian Tanaman Sayuran, Lembang, Bandung-40391, 2003.

[10] Badan Pusat Statistik, "Makassar dalam Angka 2014," 2014.

[11] P. Kavanagh, "Rapid Appraisal of Fisheries (Rapfish) Project. Rapfish Software Description (for Microsoft Excel)," Fish. Centre, Univ. Br. Columbia. Vancouver, BC, Canada, 2001.

[12] P. Kavanagh, "Implementing Microsoft Excel Software for Rapfish: A Technique for The Rapid Appraisal of Fisheries Status. University of British Columbia," Fish. Cent. Res. Reports, vol. 12, no. 2, pp. 275-450, 2004.

[13] S. Sampeliling, S. R. P. Sitorus, S. Nurisyah, and B. Pramudya, "Sustainable Urban Agriculture Development Policy: A Case Study in Jakarta," Agric. Policy Anal., vol. 10, no. 3, 2012.

[14] T. J. Pitcher and D. Preikshot, "RAPFISH: a rapid appraisal technique to evaluate the sustainability status of fisheries," Fish. Res., vol. 49, no. 3, pp. 255-270, 2001.

[15] H. De Zeeuw, "The role of urban agriculture in social and community development." Avail, 2002.

[16] L. Temple and P. Moustier, "Les fonctions et contraintes de l'agriculture périurbaine de quelques villes africaines (Yaoundé, Cotonou, Dakar)," Cah. Agric., vol. 13, no. 1, pp. 15-22, 2004.

[17] C. Aubry, A. Ba, M. H. Dabat, and J. Ramamonjisoa, "Urban agriculture and sustainable urban landscape," in 9. European IFSA Symposium, 2010, p. 2227-p.

[18] J. Moore, "Barriers and pathways to creating sustainability education programs: policy, rhetoric and reality," Environ. Educ. Res., vol. 11, no. 5, pp. 537-555, 2005.

[19] L. Parrot, J. Sotamenou, B. D. Kamgnia, and A. Nantchouang, "Determinants of domestic waste input use in urban agriculture lowland systems in Africa: The case of Yaounde in Cameroon," Habitat Int., vol. 33, no. 4, pp. 357-364, 2009.

[20] D. W. J. Foeken and S. O. Owuor, "Farming as a livelihood source for the urban poor of Nakuru, Kenya," Geoforum, vol. 39, no. 6, pp. 1978-1990, 2008.

[21] B. M. Kumar and P. K. R. Nair, "The enigma of tropical homegardens," in New vistas in agroforestry, Springer, 2004, pp. 135-152.

[22] I. Madaleno, "Urban agriculture in Belém, Brazil," Cities, vol. 17, no. 1 , pp. 73-77, 2000. 